звернення 10.01.2019 р.).

3. Шаповал М.І. Модель ділової досконалості підприємства Європейського фонду менеджменту якості. Менеджмент якості : навч. посіб. Київ : Знання, 2006. 471 с. URL: http://www.info-library.com.ua/books-text-9795.html (дата звернення 10.01.2019 p.).

4. Foresight University, The Foresight Guide, Shewhart's Learning and Deming's Quality Cycle. URL: http://www.foresightguide.com/shewhart-and-deming/ (Accessed 25.02.2019).

5. Baldrige Criteria for Performance Excellence Categories and Items. URL: https://www.nist.gov/baldrige/baldrige-criteria-commentary (Accessed 25.02.2019 p.).

6. EFQM Model. URL: https://www.toolshero.com/quality-management/efqm-model/ (Accessed 25.02.2019).

7. CAF: Common Assessment Framework. URL: http://am-one.ru/rd/pa/caf.html (дата обращения 25.02.2019 г.).

УДК 658.012.4:621

JEL класифікатор: $M 11$

Тупкало В.M.

доктор технічних наук, професор ORCIDID:0000-0002-6594-530X

Київський інститут інтелектуальної власності та права Начіонального університету «Одеська юридична академія»

\title{
БІЗНЕС-СТІЙКІСТЬ ВИРОБНИЧОГО ПІДПРИСМСТВА: КОНЦЕПЦІЯ ТА МЕХАНІЗМ ЗАБЕЗПЕЧЕННЯ
}

\section{BUSINESS-STABILITY OF MANUFACTURING COMPANY: CONCEPT AND MECHANISM OF SUPPLY}

У статті викладені розроблені автором концептуальні засади та обтрунтування моделі механізму забезпечення бізнес-стійкості виробничого підприємства на основі системного причинно-наслідкового характеру зв'язків системи бізнес-метрик управління підприємства з його комплексом маркетингу. Доведено, що кожна зі складових системи бизнес-метрик безпосередньо формує відповідні складові загальної моделі механізму забезпечення бізнес-стійкості. Тому пропонується бізнес-стійкість не зводити до синонімічно спрощено ототожнювання понять «фінансова стійкість» та "економічна стійкість», а розглядати стійкість як кортеж (комплекс) з трьох видів послідовно пов'язаних систем забезпечення стійкості «організачійна стійкість くринкова стійкість $\prec$ економічна стійкість», кожна 3 яких (система) складається з елементів функиіональних (операційних) видів стійкості. Пропонується формування чинників кожного з видів стійкості здійснювати иляхом логічного смислового об'єднання відповідної низки бізнес - політик Ріj як конкретних стратегічних поведінкових орієнтирів підприємства щчодо взаємодії з його цільовим ринком в рамках пари \{i - та бізнес - метрика, $j$ - та компонента маркетинг - мікс\}, кожний з яких (орієнтир) має економічно обтрунтований кількісний ключовий (інтегральний) показник. Визначено, щяо бізнес-стійкість - ие комплекс властивостей підприємства щэодо його спроможності швидко й адекватно реагувати на порушення в роботі технологічних бізнес-прочесів ланцююжа створення бізнес - иінності в контексті збереження довіри партнерів й 
споживачів, забезпечення конкурентоспроможності й подальшого безперервного розвитку в своій сфері бізнесу.

Ключові слова: бізнес-стійкість, бізнес-метрики управління, маркетинг-мікс, бізнес-процес.

The article describes the conceptual frame work developed by the author and the rationale for the model of the mechanism for ensuring the business sustainability of an industrial enterprise on the basis of a system-based causal relationship between the enterprise's business metrics system and its marketing complex. It is proved that each of the components of a business metrics system is directly related to the general model of the mechanism for ensuring business sustainability. There fore, it is proposed not to bring the concept of "business sustainability" to the synonym of the concepts "financial sustainability" and "economic sustainability", but to consider sustainability as a tuple (complex) of three types of consistently related sustainability systems- "organizational sustainability", < market sustainability $<$ economic sustainability ", and each system of stability consists of elements - functional (operational) types of stability. It is proposed to create the factors of each type of sustainability by means of the logical semantic association of the corresponding series of business politician Rij as specific strategic behavioral orientations of the enterprise on interaction with its target market within the framework of the pair $\{i$ - the business metric, $j$ is the component of the marketing complex\}, each of which (landmark) has an economically justified quantitative key (integral) indicator. It was determined that business sustainability is a complex of enterprise properties according to its ability to quickly and adequately respond to violations in technological business processes of the business creation chain - values in the context of maintaining the trust of partners and consumers, ensuring competitiveness and further continuous development in their business.

Key words: business stability, business metrics management, marketing mix, business process.

Вступ. В сучасних ринкових умовах господарювання економічна криза, як явище, набирає все більше регіональних та національних масштабів. За таких умов доцільно грунтовно вивчити фактори, що обумовлюють бізнесстійкість виробничого підприємств як комплексу взаємодії певного набору його бізнес-метрик управління відносно впливу факторів його зовнішнього бізнес-середовища, систематизувати існуючі наукові підходи і розробити нові, більш дієві методичні засади системного підходу щодо забезпечення бізнес-стійкості. В контексті загальної проблеми забезпечення бізнесстійкості сучасних підприємств існує багато публікацій, в яких автори намагаються поняття «бізнес-стійкість» синонімічно спрощено звести до поняття «фінансова стійкість» або «економічна стійкість» [11,14] у відриві від причинно-наслідкового характеру зв'язків системи бізнес-метрик управління підприємства 3 його маркетинг-міксом, які (зв'язки) є елементами системного механізму забезпечення досягнення генеральної бізнес-цілі суб'єктів господарювання в довгостроковому періоді. Прикладами такого спрощення $\epsilon$ звісні адитивні дискримінантні моделі оцінки банкрутства[1,2,10]: Е. Альтмана (1968p.), Р.Ліса (1972p.), Чессера (1974p.), Р.Таффлера (1977р.), Давидової - Бєлікова (1999р.). С спроби визначення поняття «бізнес-стійкість» через евристичний (механістичний) перелік факторів можливих бізнес-ризиків для підприємств без відносно до його системній бізнес-моделі стратегічного розвитку [3,4,5]. Все це вказує на те, 
що поняття стійкості господарюючого суб'єкта є багатофакторним i багатоплановими тому ця тема досліджень ще далека від завершення.

Постановка завдання. Метою дослідження є обгрунтування концепції та механізму забезпечення бізнес-стійкості виробничого підприємства (далі підприємство) на основі системного причинно-наслідкового характеру зв'язків системи бізнес-метрик управління підприємства 3 його маркетингміксом [12,13]. Згідно цієї мети бізнес - стійкість пропонується розглядати як комплекс властивостей підприємства щодо його спроможності швидко й адекватно реагувати на порушення в роботі технологічних бізнес - процесів ланцюжка створення бізнес - цінності в контексті збереження довіри партнерів й споживачів (клієнтів), забезпечення конкурентоспроможності й подальшого безперервного розвитку в своїй сфері бізнесу.

Методологія. При проведенні дослідження використовувались методи порівняння та узагальнення, метод аналізу для уточнення базового категоріального апарату формованої сьогодні теорії процесного управління.

Результати дослідження. Звісно, що кожне підприємство в рамках формування власного механізму управління бізнес - стійкістю, спирається, в першу чергу, на вдосконалення системи управління. При цьому використання системного підходу дозволяє розглядати управління бізнес стійкістю через систему різних напрямків управління підприємством (систему бізнес-метрик, англ. SBC - system of business coordinates $[6,12])$, які i $є$ об'єктами аналізу щодо забезпечення бізнес-стійкості. Причому кожна зі складових системи бізнес-метрик безпосередньо впливає не тільки на кінцевий результат, а й один на одного, формуючи при цьому власний механізм управління підприємством i його конкурентоспроможністю. Виходячи з цього, в основу дослідження покладено авторську концептуальну модель аналізу та синтезу механізму забезпечення бізнес-стійкості підприємств [8], яка представлена на рис.1 у вигляді прямого і зворотного причинно-наслідкових ланцюжків оцінки ефективності взаємодії елементів бізнес - середовища підприємства у наступному визначенні:прямий ланц̧южок - тільки ефективний харизматичний власник бізнесу на чолі висококваліфікованого мотивованого персоналу, який використовує сучасний інформаційно - технологічний ресурс (IT-ресурс) у своїй операційній діяльності, здатний реалізувати ефективну систему управлінських і технологічних бізнес - процесів взаємодії з суб'єктами ринку (постачальниками, клієнтами, інвесторами, конкурентами) по ланцюжку створення споживчої цінності, що у свою чергу зумовить стійке конкурентоспроможне співвідношення ціна / якість продаваних товарів (послуг) i у кінцевому підсумку забезпечить бажану (плановану) динаміку i величину прибутку на вкладений капітал власників (акціонерів, інвесторів) підприємства; зворотній ланцюжок - причини незадовільних значень фінансово-економічних показників слід шукати у блоці «Споживачі / Ринок», незадоволеність споживачів означає наявність проблем у блоках «Бізнеспроцеси» та «ІТ-ресурс», а коріння проблем 3 управлінськими та 
технологічними бізнес-процесами знаходяться у блоці «Персонал» щодо факторів кваліфікація, мотивація, використання сучасного інформаційно технологічного ресурсу.

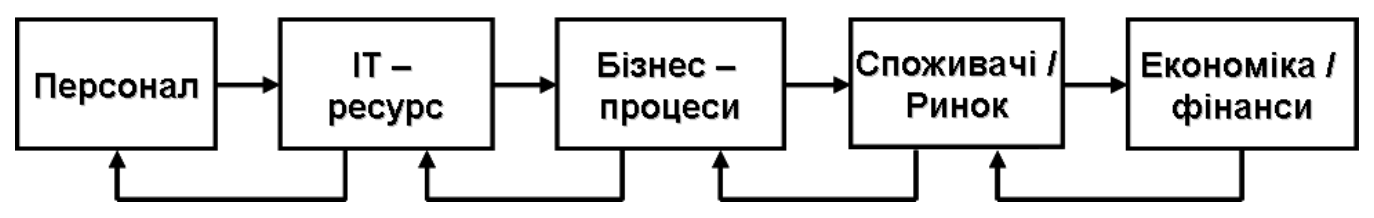

Рисунок 1 - Модель причинно-наслідкових ланцюжків оцінки ефективності взаємодії елементів бізнес - середовища підприємства (авторська модель)

В контексті проблеми забезпечення бізнес-стійкості підприємства щодо пропонованої моделі рис.1 слід зазначити: на нашу думку можна стверджувати, що головним визначальним чинником успішного розвитку будь-якого бізнесу є життєві цінності і методи управління (менеджменту) першого керівника (власника бізнесу). Цей чинник у подальшому $\epsilon$ визначальним у процесі формування якості найнятого персоналу та інфраструктури, що у подальшому обумовить рівень корпоративної культури підприємства. В свою чергу, корпоративна культура в значній мірі $є$ вхідною умовою забезпечення належної якості (ефективності) технології бізнесу у всіх напрямках господарської діяльності створеного підприємства, що має вирішальне значення у вирішенні цільової бізнес-задачі «створи свого споживача». В кінцевому рахунку, успішне вирішення цієї бізнес-задачі забезпечує необхідний об'єм збуту товарів/послуг, тобто рівень прибутку, який $є$ кількісною мірою, що характеризує бізнес-стійкість підприємств як якість комплексу взаємодії певного набору бізнес-метрик управління підприємства відносно впливу факторів його зовнішнього бізнес-середовища.

Виходячи 3 результатів апробації вищевикладеного в процесі виконання автором низки консалтингових проектів щодо оптимізації системи менеджменту виробничих підприємств різних сфер бізнесу, пропонована модель створення механізму забезпечення бізнес-стійкості виробничого підприємства представлена на рис.2. Базовою основою цієї моделі $\epsilon$ авторська матриця стратегічного планування «BSC-4P» [9] та їі подальша модифікація « $\mathrm{SBC}-\mathrm{MM}$ [ [7]. 


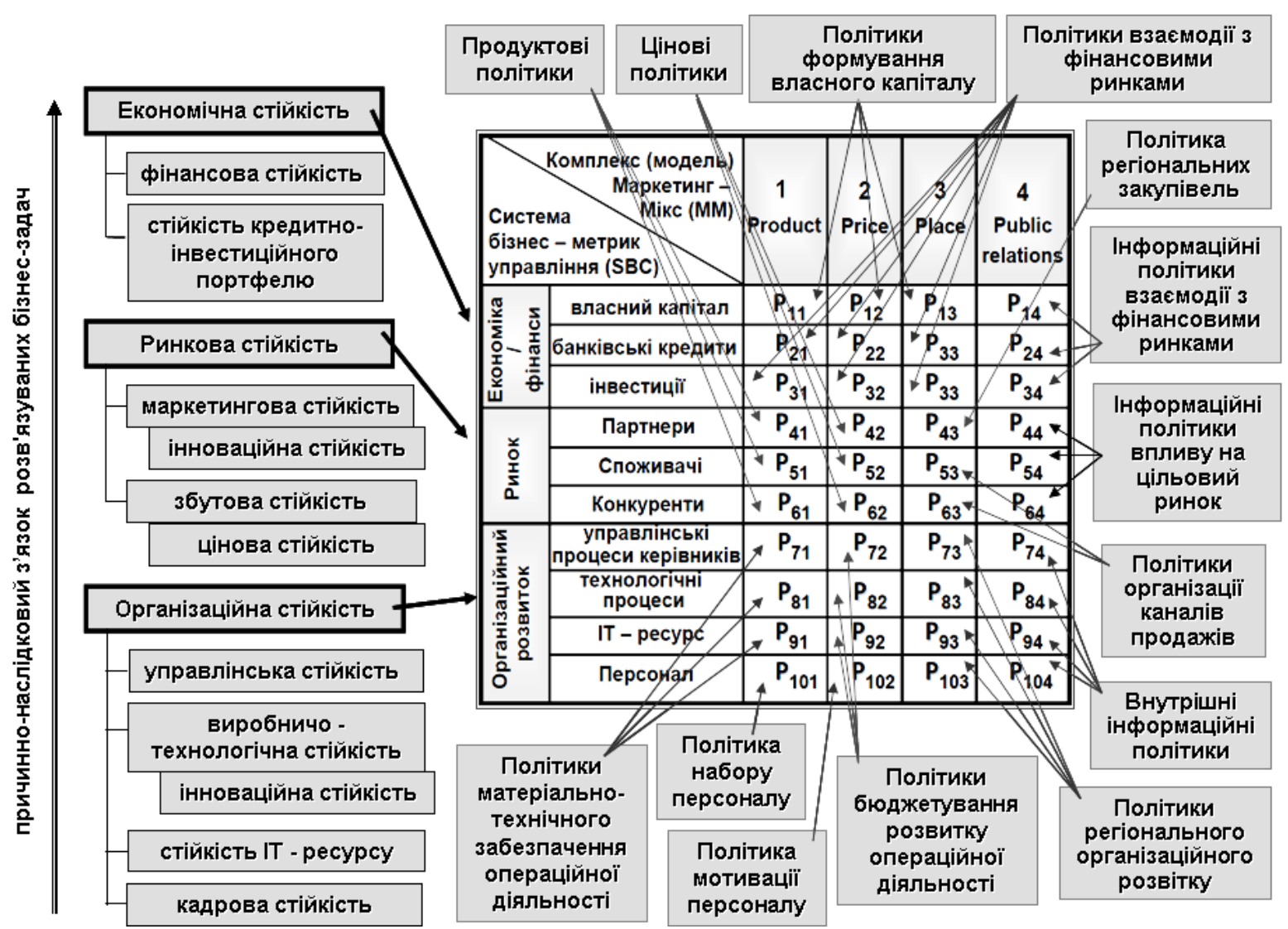

Рисунок 2 - Модель створення механізму забезпечення бізнес-стійкості підприємства на основі матриці стратегічного планування «SBC - MM» (авторська модель)

Згідно причинно-наслідкового з'язку розв'язуваних бізнес-задач моделі рис.2 категорію «бізнес-стійкість» пропонується розглядати як кортеж (комплекс) 3 трьох видів послідовно пов'язаних систем забезпечення

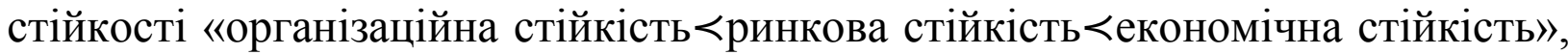
кожна 3 яких (система) складається 3 елементів - функціональних (операційних) видів стійкості. При цьому слід зауважити, що сутність кожного виду функціональної стійкості $\epsilon$ відображенням специфіки конкретного підприємства і тому кожний вид стійкості має свій набір суттєвих чинників, які потребують ретельного аналізу. Крім того,формування чинників кожного 3 видів стійкості пропонується здійснювати шляхом логічного смислового об'єднання відповідної низки бізнес - політик $\mathrm{P}_{\mathrm{ij}}$ як конкретних стратегічних поведінкових орієнтирів підприємства щодо взаємодії з його цільовим ринком в рамках пари $\{\mathrm{i}$ - та бізнес - метрика, $\mathrm{j}$ - та компонента маркетинг - мікс\}, кожний з яких (орієнтир) має економічно обгрунтований кількісний ключовий (інтегральний) показник $\mathrm{d}_{\mathrm{ij}}$. Наприклад, тлумачення поняття «управлінська стійкість» MS (manageria lstability) в

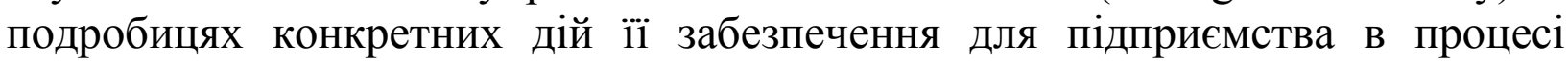
стратегічного планування організаційного розвитку грунтується на логічному смисловому об'єднанні (U) відповідної низки (кортежу)бізнес - політик: 


$$
\mathrm{MS}=\mathrm{P}_{71} \mathrm{UP}_{72} \mathrm{UP}_{73} \mathrm{UP}_{74} \cdot(1)
$$

Виходячи 3 моделі рис.2, комплексну категорію «бізнес-стійкість» підприємства пропонується визначати як сукупність наступних видів стійкості.

Кадрова стійкість - здатність підприємства залучати, постійно розвивати та удержувати висококваліфікований персонал шляхом створення ефективної сприятливої для досягнення бізнес - цілей корпоративної культури та системи заохочення (стимулювання праці).

Стійкість IT-ресурсу - здатність підприємства протидіяти кіберзлочинам шляхом захисту своєї цінної інформації від розкриття, крадіжок, зміни контенту, знищення та пошкодження; захистити персональну інформацію клієнтів, співробітників і партнерів; знизити ризики збою роботи апаратно-програмних засобів в процесах обробки цінної інформації.

Виробничо - технологічна стійкість (стійкість системи технологічних процесів виробничої діяльності) - здатність функціонального персоналу технологічних процесів ланцюжка створення споживчої цінності підприємства [16] забезпечити мінімально прийнятний рівень ймовірності виникнення критичних ситуацій в процесах та величини комерційних збитків їх наслідків.

Інноваційна стійкість виробничо - технологічної діяльності - здатність функціонального персоналу $\mathrm{i}$ керівників (власників) технологічних виробничих процесів ланцюжка створення споживчої цінності постійно створювати й комерціалізувати інтелектуальну власність, яка забезпечує конкурентоспроможність товарів / послуг підприємства на його цільовому ринку.

Управлінська стійкість (стійкість системи управлінських процесів керівників) - здатність керівного складу підприємства швидко і адекватно реагувати на порушення в роботі управлінського циклу «плануй - організуй контролюй - аналізуй - впливай» [17] безпосередньо підлеглого (підлеглих) об'єкта (об'єктів) управління, забезпечуючи подальший організаційний розвиток свого ієрархічного рівня управлінської відповідальності.

Організаційна стійкість - здатність підприємства як бізнес - системи забезпечити стабільність внутрішньої процесно - орієнтованої організаційної структури управління шляхом дотримання чотирьох базових системоутворюючих принципів побудови організаційних систем: ієрархічність, детермінованість, цілісність (повнота й несуперечливість), синергетичність [6].

Цінова стійкість - здатність підприємства в процесі збутової діяльності забезпечити оптимальний механізм ціноутворення товарів / послуг, який дозволить 3 найбільшим ефектом планувати стійкий рівень збуту в натуральних одиницях. 
Збутова стійкість - здатність підприємства організувати такий рух потоків товарів / послуг, який би забезпечував постійне перевищення надходження доходів над витратами.

Маркетингова стійкість - здатність підприємства своєчасно реагувати на зовнішні зміни ринкової кон'юнктури і конкурентних чинників шляхом корекції комплексу маркетингу (маркетинг - міксу) без порушення організації функціонування бізнес - процесів ланцюжка створення споживчої цінності i не припиняючи подальший цільовий розвиток комерційної діяльності.

Інноваційна стійкість маркетингової діяльності - здатність персоналу маркетингового підрозділу підприємства щодо залучення споживачів шляхом постійного створювання і реалізації в своїй діяльності інноваційні методів та способів (ноу-хау) інформаційного економіко-ефективного комерційного впливу на фокус-групи споживчого ринку.

Ринкова стійкість - здатність підприємства своєчасно адаптуватися до змін ринкової кон'юнктури та конкуренції, зберігаючи незмінність функціонування та свою частку ринку протягом довгострокового періоду, шляхом корекції існуючої товарної і цінової політики зі збереженням рівня фінансової стійкості або шляхом оперативної технологічної перебудови ланцюжка виробничих процесів 3 метою переходу на створення нової актуальної споживчої цінності (створення нових бізнес - юнітів), зберігаючи рівновагу своїх активів і пасивів, щоб гарантувати платоспроможність та інвестиційну привабливість у межах допустимого рівня ризику.

Стійкість кредитно - інвестиційного портфеля - здатність підприємства ефективно управляти існуючим кредитно - інвестиційним портфелем і при необхідності залучати додаткове зовнішне фінансування відповідно до своєї оцінки припустимого рівня бізнес - ризику.

Фінансова стійкість - здатність підприємства у короткостроковому та середньостроковому періоді згідно сформованого комплексу бізнес-політик стратегічного планування «Бізнес-координати управління - Комплекс маркетингу» раціонально управляти власним і позиковим капіталом з метою виконання всіх фінансових зобов'язань перед персоналом, партнерами, державою, завдяки достатньому доходу.

Економічна стійкість (EVA-стійкість [16]) - здатність підприємства у довгостроковому періоді зберігати в умовах динамічної трансформації взаємодії його внутрішнього та зовнішнього бізнес - середовища певний (заздалегідь заданий) рівень досягнення генеральної бізнес-цілі запланованого рівня економічної доданої вартості EVA (англ. Economic Value Added). В якості моделі механізму забезпечення EVA-стійкості пропонується обрати сформовану на основі матриці стратегічного планування «SBC - MM» (див.рис.2)модель дерева генеральної бізнес-цілі у вигляді піраміди EVA, яка має сенс за аналогією з відомою пірамідою Дюпона (DuPont) у такому визначенні: це управлінський інструмент багатофакторного причиннонаслідкового аналізу, що дозволяє визначити, за рахунок яких 
взаємопов'язаних в системі чинників господарської діяльності підприємства відбувається зміна економічно доданої вартості. Мірою кількісної оцінки економічної стійкості пропонується вважати долю прибутку згідно точки EVA-беззбитковості [6] у величині фактично отриманого доходу (коефіцієнт економічної стійкості $\mathrm{K}_{\mathrm{EC}}$ ):

$$
\mathrm{K}_{\mathrm{EC}=1-} \frac{\text { Постійні витрати }+ \text { Залучений капітал }}{\text { Маржинальний дохід }}
$$

де WACC - середньозважена вартість залученого у бізнес капіталу.

Виходячи 3 моделі рис.2, а саме: враховуючи причинно-наслідковий зв’язок розв'язуваних бізнес-задач підприємства в контексті ланцюгових дій щодо аналізу (оцінки) динаміки економічних показників стійкості окремих напрямків господарської діяльності в стратегічному циклі управління підприємством, пропонується задачу формалізації інтегрованого показника

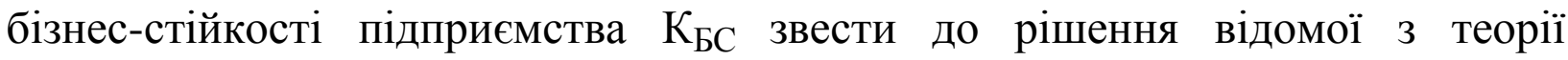
статистики задачі розрахунку середньо геометричної [15] від перемноження сукупності $n$ окремих відносних показників - характеристик $\mathrm{K}_{\mathrm{i}}$ бізнес стійкості ланцюжка створення механізму забезпечення бізнес-стійкості підприємства (див. модель рис.2):

$$
\mathrm{K}_{\mathrm{bC}}=\sqrt{\mathrm{K}_{1} \times \mathrm{K}_{2} \times \ldots \times \mathrm{K}_{n}}
$$

Альтернативою для (3) може бути модифікована модель:

$$
\mathrm{K}_{\mathrm{EC}}=\sqrt{\left(\mathrm{BK}_{1} \times \mathrm{K}_{1}\right) \times\left(\mathrm{BK}_{2} \times \mathrm{K}_{2}\right) \times \ldots \times\left(\mathrm{BK}_{n} \times \mathrm{K}_{n}\right)},
$$

де $\mathrm{BK}_{1}, \mathrm{BK}_{2}, \ldots, \mathrm{BK}_{\mathrm{n}}$ - вагові коефіцієнти, які призначаються експертами шляхом.

Висновки. Наукова новизна проведеного дослідження полягає у формуванні нової концепції оцінки бізнес-стійкості підприємств, яка грунтується на системному причинно-наслідковому характеру зв'язків системи бізнес-метрик управління підприємства 3 його маркетинг - міксом $\mathrm{i}$ тому категорія «бізнес-стійкість» розглядається як кортеж 3 трьох видів послідовно пов'язаних систем забезпечення стійкості «організаційна

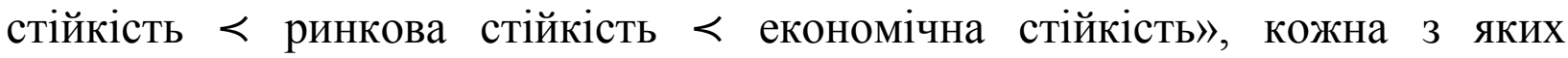
(система) складається 3 елементів - функціональних (операційних) видів стійкості згідно авторської матриці стратегічного планування «SBC - MM». Перспектива подальших досліджень пов'язана 3 вирішенням завдання формування систем кількісного трендового аналізу стійкості ланцюжків створення бізнес-цінності для кожної бізнес-метрики виробничого підприємства 3 урахуванням запропонованої моделі створення механізму забезпечення бізнес-стійкості підприємства на основі матриці стратегічного планування «SBC - MM». 


\section{Література:}

1. Шапурова О.О.Моделі оцінки банкрутства та кризового стану підприємств. Економіка та держава. 2009. №4. С.59-64.

2. Ліндер С. Еволюція моделей оцінки ймовірності банкрутства. Науковий вісник МНУ імені В.О. Сухомлинського. Економічні науки. 2016. №1(6). С.125-129.

3. Голь І.В. Бізнес-стійкість підприємства:бізнес-цільовий процесно-орієнтований підхід. Телекомунікаційні та інформаційні технологї. 2014. №3. С. 101-105.

4. Окладский П.В. Соотношение понятий экономической несостоятельности и устойчивости предприятий. Лесной журнал. 2010. № 5 С. 176-80.

5. Григорян Е. С. Классификация видов устойчивости предприятия . Конщепт : научнометодический электронный журнал. Електронні дані. [РФ, г. Киров: Автономная некоммерческая организация дополнительного профессионального образования «Межрегиональный центр инновационных технологий в образовании]. 2015. № 3. URL: https://e-koncept.ru/2015/15072.htm (дата звернення 23.10.2018 p.).

6. Тупкало В.М. Бізнес - інжиніринг сучасних процесно - орієнтованих підприємств: монографія. К.: ДУТ. 2016. 281 с.

7. Тупкало С.В., Тупкало В.Н. Методика формирования системы сбалансированных показателей оценки эффективности управления предприятием. Системи управління, навігації та зв'язку: зб. наук. пр. К.: ЦНДІНУ, 2011. №. 3(19). С.169-175.

8. Тупкало В.М., Голь І.В. Модель комплексної оцінки бізнес - стійкості телекомунікаційного підприємства / В.М. Тупкало, І.В. Голь // VIII Всеукраїнська науково - практична конференція «Сучасні підходи до управління підприємством»: зб. тез. доп. - К.: Вид-во «Політехніка», 2017.- С.36.

9. Тупкало В.Н. Методика разработки модели системы процесно -ориентированного стратегического управления предприятием / С.В.Тупкало, В.Н. Тупкало // Системи управління, навігації та зв’язку: зб. наук. пр. - К.: ЦНДІНУ, 2008. - Вип. 4(8). - С.113 119.

10. Рзаєва Т.Г. Зарубіжні методики визначення ймовірності банкрутства підприємства / Т.Г. Рязаєва, І.В. Стасюк // Вісник Хмельницького національного університету. - 2010. №3. Т.1. - С.177 - 181 .

11. Чернякова И.С. Построение структурно-дискурсивного алгоритма процесса обеспечения экономической устойчивости мясоперерабатывающих предприятий. Весник института экономических исследований. 2017. № 2(6). С.66-71.

12. Тупкало С.В. Методика решения задачи оптимизации организационной структуры процессно - ориентированного предприятия на основе принципа «Структура следует за стратегией» / С.В. Тупкало, В.Н. Тупкало // Системи управління, навігації та зв'язку: зб. наук. пр.- К.: ЦНДІНУ, 2009.- Вип.3(11).- С.69 - 76.

13. Тупкало С.В., Батенко Л.П. Обгрунтування моделі процесно - орієнтованого управління діяльністю електропостачального підприємства. Ефективна економіка № 7 , 2012. С. 18-24.

14. Недосекин А. О., Рейшахрит Е. И. К вопросу определения категории «экономическая устойчивость» для сырьевых отраслей. [Електронний ресурс]- Режим доступу: https://novainfo.ru/article/10801

15. Лахтіонова Л.А. Економічна категорія "фінансова стійкість" в сучасному фінансовому аналізі підприємницької діяльності / Л.А. Лахтіонова // Наук. пр. Кіровоград. нац. техн. ун-ту. екон. науки: Зб. наук. праць. - 2009. - Вип. 6, ч. II. - С. 327-338. 16. Тупкало В.М. Управління економічною доданою вартістю підприємства на основі механізму контролінгової піраміди виручки / В.М. Тупкало // Економіка. Менеджмент. Бізнес: зб. наук. праць. - К.: ДУТ. - Вип.2(10), 2014.- С.5 - 13. 
17. Тупкало В.Н. Проблема понятийной базы методологии процессного менеджмента / С.В.Тупкало, В.Н.Тупкало// Das Management. - 2010.- № 5. - С. 15-20.

Шевчук О.А. канд. економ. наук, доцент ORCID ID: 0000-0003-4117-1474

Національний технічний університет Украӥни «Київський політехнічний інститут імені Ігоря. Сікорського»

\section{ОСНОВНІ ПРИНЦИПИ ЗАБЕЗПЕЧЕННЯ ДИНАМІЧНӦ̈ СТІЙКОСТІ РОЗВИТКУ ПІДПРИЕМСТВ НА ЗАСАДАХ БІЗНЕС- ЛІДЕРСТВА}

\section{BASIC PRINCIPLES OF SUPPORTING THE SAME STABILITY OF DEVELOPMENT OF ENTERPRISES ON THE BASIS OF BUSINESS LEADERSHIP}

В межах статті проведено аналіз основних принципів забезпечення стійких конкурентних переваг, щуо дозволило виявити семантичні закономірності розвитку вітчизняних підприємства в сучасних умовах господарювання.

3 метою обтрунтування принщипів, щуо визначають можливість отримання підприємством високих позииій на ринку, визначено основні переваги становлення бізнеслідерства, серед яких основними виступають: 1) влада, щзо трунтується на здатності товаровиробника здійснювати вплив на ринкову кон'юнктуру задля власних економічних інтересів; 2) імідж, щчо свідчить про ступінь довіри до підприємства з боку ділових партнері $i$ споживачів продукиії; 3) прибуток, що характеризує сукупний результат виробничо-комериійної діяльності підприємства. На основі аналізу означених чинників, визначено, що бізнес-лідерство ие елемент ринкового механізму, який може змінювати свою природу в умовах трансформації конкурентоспроможності інноваційної продукції та забезпечується людським капіталом підприємства за рахунок підвищення якості управління.

Автором обтрунтовано, щуо необхідною умовою досягнення ијільової функиії має бути дотримання комплексу певних принципів розвитку. Автором доведено, щэо в основі таких принципів лежить ланцюг створення иінності (value chain), щзо пов'язує систему управління зі стратегією розвитку. До складу таких принципів, автор відносить загальнонаукові принципи діалектики (детермінізму, об'єктивності, причинності, послідовності та раціональності); системні принципи (ціле встановлення, розвитку, ієрархічності, множинності, інериійності, зворотного зв'язку, моніторингу та моделювання); специффічні - гомеостазу, пріоритету та відповідності, превентивності, методологічного колективізму та функиіоналізму, організаційної архітектоніки, інклюзивності, мотивації та соціальної відповідальності.

Автором доведено, що застосування означених принщипів на підприємстві сприяє підвищенню ефективності діяльності за рахунок узгодженості иілей суб'єкту та об'єкту управління. 